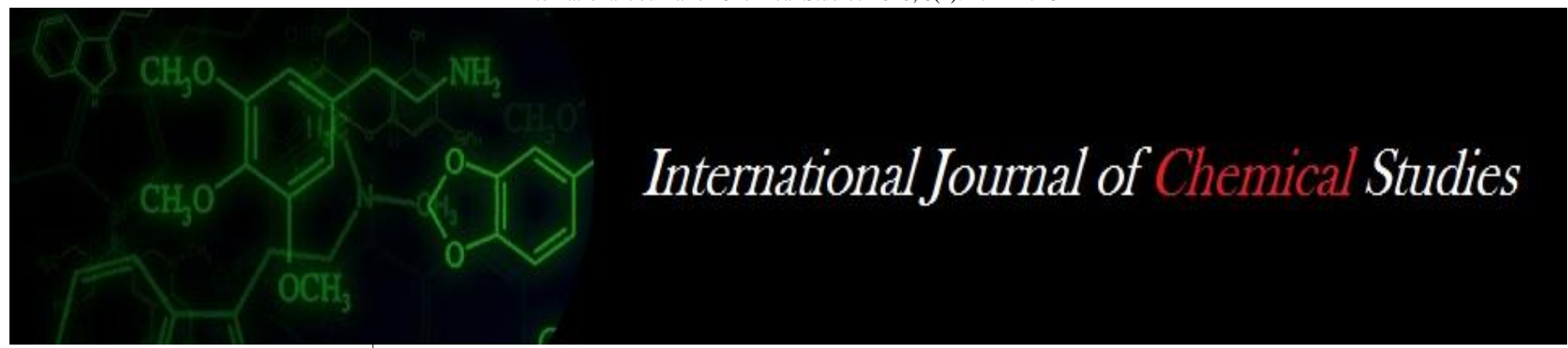

P-ISSN: 2349-8528

E-ISSN: 2321-4902

www.chemijournal.com

IJCS 2020; 8(4): 2722-2728

(C) 2020 IJCS

Received: 18-05-2020

Accepted: 22-06-2020

\section{Obadiya Rai}

Department of Fruit Science,

College of Horticulture,

Bagalkot, University of

Horticultural Sciences, Bagalkot,

Karnataka, India

\section{SN Patil}

Department of Fruit Science,

College of Horticulture,

Arabhavi, University of

Horticultural Sciences, Bagalkot,

Karnataka, India
Corresponding Author:

\section{SN Patil}

Department of Fruit Science,

College of Horticulture,

Arabhavi, University of

Horticultural Sciences, Bagalkot,

Karnataka, India

\section{Influence of plant growth regulators and potassium nitrate on the qualitative parameters of acid lime (Citrus aurantifolia Swingle) during hasta Bahar in Northern dry zone of Karnataka}

\author{
Obadiya Rai and SN Patil
}

DOI: https://doi.org/10.22271/chemi.2020.v8.i4af.10058

\begin{abstract}
Qualitative parameters of acid lime (Citrus aurantifolia Swingle) were found to be influenced with the different concentrations of plant growth regulators and chemical during hasta bahar. GA 3 @ 50 ppm in June - Cycocel @ 1000 ppm in September - $\mathrm{KNO}_{3} @ 2 \%$ in October resulted in maximum titrable acidity (7.19), total soluble solids (7.25), total sugar (1.81), reducing sugars $(0.87)$, non-reducing sugars $(0.94)$ and minimum number of seeds (8.06). However, the maximum juice percent (49.31) and least rind thickness were found in GA3 @ 50 ppm in June - Cycocel @ 2000 ppm in September - $\mathrm{KNO}_{3} @ 2 \%$ in October. Similarly, the maximum ascorbic acid (30.46) and least weight of seeds per fruit $(0.62)$ were found in $\mathrm{GA}_{3} @ 50$ ppm in June - Cycocel @ 1500 ppm in September - $\mathrm{KNO}_{3} @ 2 \%$ in October and $\mathrm{GA}_{3} @ 50$ ppm in June respectively.
\end{abstract}

Keywords: Acid lime, hasta bahar, plant growth regulators, chemicals

\section{Introduction}

Acid lime is botanically known as Citrus aurantifolia Swingle belongs to the family, Rutaceae and has chromosome number $(2 n=18)$. It is considered third most commercially important citrus fruit just next to mandarin and sweet orange among citrus species with an annual production of 2.84 million tonnes and productivity of $9.90 \mathrm{MT} / \mathrm{ha}$ (Anon, 2017) ${ }^{[1]}$. The major growing states includes Andhra Pradesh, Telangana, Karnataka, Odisha, Madhya Pradesh, Maharashtra and minorly in Assam, Bihar, Chhattisgarh, Manipur, Jharkhand, Tamil Nadu, Tripura, and Mizoram. Acid limes are usually used as fresh fruit or in preparation of pickles and beverages. It is a good source of vitamin $\mathrm{C}$ and has a good anti-oxidant property. It helps in neutralizing the radical particles in human guts and act as a coolant during summer. It is well-liked and appreciated for its appearance, pleasing flavor and better fruit qualities.

In south Indian conditions, the flowering in acid lime occurs in three seasons with varying percentages. As reported by Pawar et al. (2016) ${ }^{[25]}$, the flowering percentage of ambe, mrig and hasta bahar occurs as 47\%, 36\% and $17 \%$ respectively. However, the high demand of acid lime during summer months has widened up the scope for manipulation of flowering and harvesting of fruits during April to May. Despite of several conventional methods for flower manipulation and crop regulation, which does not hold true influence under different conditions in acid lime. This has led to the advent of plant growth regulators and chemical to regulate flowering in acid lime with maximum production and better qualities of fruits. Better quality fruits with high juice content, ascorbic acid, titrable acidity with less seeds per fruit and thinner rind are always marketed with high prices which helps in fetching increased remunerative to the growers. However, citrus canker and leaf miner are the major constraints in the production and quality of acid lime. Therefore, the present study was conducted to investigate the effect of different concentration of PGRs and chemical on biochemical parameters of acid lime during hasta bahar as well as pest and disease incidence.

\section{Materials and Methods}

Experiment was conducted on five years old acid lime (Citrus aurantifolia Swingle) trees with the spacing of $6 \mathrm{~m} \times 6 \mathrm{~m}$. The experimental site was geographically located at an altitude of 629 
$\mathrm{m}$ from mean sea level and latitude $16.97^{\circ} \mathrm{N}$ and longitude $75.75^{\circ}$ E. The experiment was laid out in split plot design with two varieties of acid lime as main plot treatment and different combination of plant growth regulators and chemical as sub plot treatment with three replications. The experimental details are showed in the table below as follows:

Table 1: Shows main plot treatments

\begin{tabular}{|c|c|}
\hline \multicolumn{2}{|r|}{ Main plot treatments } \\
\hline $\mathrm{M}_{1^{-}}$ & Phule Sharbati \\
\hline $\mathrm{M}_{2^{-}}$ & Sai Sharbati \\
\hline \multicolumn{2}{|r|}{ Sub-plot treatments } \\
\hline $\mathbf{S}_{\mathbf{1}^{-}}$ & $\mathrm{GA}_{3} @ 50 \mathrm{ppm}$ in June \\
\hline $\mathbf{S}_{2^{-}}$ & $\mathrm{KNO}_{3} @ 2 \%$ in October \\
\hline $\mathbf{S}_{3-}$ & Cycocel @ 1000 ppm in September \\
\hline $\mathbf{S}_{4^{-}}$ & Cycocel @ 1500 ppm in September \\
\hline $\mathbf{S}_{5^{-}}$ & Cycocel @ 2000 ppm in September \\
\hline $\mathbf{S}_{6^{-}}$ & $\mathrm{GA}_{3} @ 50 \mathrm{ppm}$ in June - Cycocel @ 1000 ppm in Sept - $\mathrm{KNO}_{3} @ 2 \%$ in October \\
\hline $\mathbf{S}_{7^{-}}$ & $\mathrm{GA}_{3} @ 50 \mathrm{ppm}$ in June - Cycocel @ $1500 \mathrm{ppm}$ in Sept - $\mathrm{KNO}_{3} @ 2 \%$ in October \\
\hline $\mathbf{S}_{8^{-}}$ & $\mathrm{GA}_{3} @ 50 \mathrm{ppm}$ in June - Cycocel @ $2000 \mathrm{ppm}$ in Sept - $\mathrm{KNO}_{3} @ 2 \%$ in October \\
\hline $\mathbf{S}_{9^{-}}$ & Control (No spray) \\
\hline
\end{tabular}

Accordingly, the different concentration of growth regulators and chemical were prepared by dissolving them in ethanol and applied as foliar spray with knapsack sprayer until the trees were completely wet. The titrable acidity of the juice was determined according to method described in A.O.A.C. $(1975)^{[2]}$. The total soluble solid were estimated with digital hand refractometer. Ascorbic acid was estimated by titration against standard dye (2, 6-dichlorophenyl). Similarly, the reducing and total sugars were estimated using Di-nitro salicylic (reagent) method and Anthrone (reagent) method respectively. The data collected were subjected to Fisher ' $F$ ' test. The degree of probability employed in deciding the critical difference was 5 percent $(\mathrm{P}=0.05)$.

\section{Results and Discussion}

The experimental results obtained from the present investigation are summarized as follows:

\section{Effect of plant growth regulators and chemical on qualitative parameters of acid lime \\ Juice (\%)}

The juice percentage was significantly influenced by the application of plant growth regulators and chemicals. However, there were no-significant differences found in main plot and significant differences in sub plot and interactions. The maximum juice percent $(49.31 \%)$ was obtained in $\mathrm{S}_{8}$ $\left(\mathrm{GA}_{3} @ 50\right.$ ppm in June - Cycocel @ 2000 ppm in September - $\mathrm{KNO}_{3} @ 2 \%$ in October) which was statistically significant over the other treatment and was on par with $\mathrm{S}_{6}(47.46 \%)$ and $\mathrm{S}_{7}(45.66 \%)$. These results are in similarity with the findings of Mukunda et al., (2014) ${ }^{[24]}$, Pawar et al. (2016) ${ }^{[25]}$ and Ranganna et al. (2017) ${ }^{[28]}$ respectively.

Similar findings which increased juice percentage with gibberellins were reported by Kumar et al. (1975) ${ }^{[21]}$ in sweet lime, Mazumdar and Bhatt (1976) ${ }^{[22]}$, Khalid et al. (2012) ${ }^{[18]}$ in Kinnow mandarin, Sandhu (2013) ${ }^{[30]}$ in lemon, Baghdady et al. (2014) ${ }^{[3]}$ in Valencia orange, Rokaya et al. (2016) ${ }^{[29]}$ in mandarin and with cycocel were reported by Brahmachari et al. (1995) ${ }^{[7]}$ in guava. Similar results were obtained with potassium nitrate were reported by Debaje et al. (2011) ${ }^{[11]}$ and Khayyat et al. (2012) ${ }^{[19]}$ in pomegranate.

\section{Titrable acidity $(\%)$}

Titrable acidity had been significantly influenced by the application of plant growth regulators and chemicals in main plot, sub plot and interactions. In main plot, the maximum titrable acidity was found in $\mathrm{M}_{2}(6.80 \%)$ and followed by $\mathrm{M}_{1}$ (6.39\%). As regard to sub plot, the maximum titrable acidity (7.19\%) was observed in $\mathrm{S}_{6}\left(\mathrm{GA}_{3} @ 50 \mathrm{ppm}\right.$ in June Cycocel @ 1000 ppm in September - $\mathrm{KNO}_{3} @ 2 \%$ in October) and was found to be on par with $\mathrm{S}_{7}(21.32 \%)$. However, the minimum titrable acidity $(5.46 \%)$ was observed in $\mathrm{S}_{2}$ i.e. $\mathrm{KNO}_{3}$ @ $2 \%$ in October.

Similar results were obtained by Rattanpal et al. (2008) where in maximum acidity was observed in $\mathrm{KNO}_{3} 5 \%+2$, 4-D @ 20 ppm when sprayed 60 days after full bloom and Debbarma and Hazarika (2016) ${ }^{[12]}$ in which $\mathrm{GA}_{3} 100$ ppm - Cycocel $1000 \mathrm{ppm}-\mathrm{KNO}_{3} 1$ per cent resulted in higher titrable acidity $(8.27 \%)$ but contradicted with the findings of Debaje et al. $(2011)^{[11]}$ which reported reduced acidity and peel percentage with $\mathrm{KNO}_{3}\left(2\right.$ per cent) and $\mathrm{GA}_{3}(100 \mathrm{ppm})$.

Table 2: Effect of plant growth regulators and chemical on juice, titrable acidity, TSS and ascorbic acid in different cultivars of acid lime

\begin{tabular}{|c|c|c|c|c|c|c|c|c|c|c|c|c|}
\hline \multirow{2}{*}{ Treatments } & \multicolumn{3}{|c|}{ Juice (\%) } & \multicolumn{3}{|c|}{ Titrable acidity (\%) } & \multicolumn{3}{|c|}{ TSS $\left({ }^{\circ}\right.$ Brix $)$} & \multicolumn{3}{|c|}{ Ascorbic acid (mg/100ml juice) } \\
\hline & $\mathbf{M}_{1}$ & $\mathbf{M}_{2}$ & Mean & $\mathbf{M}_{1}$ & $\mathbf{M}_{2}$ & Mean & $\mathbf{M}_{1}$ & $\mathbf{M}_{2}$ & Mean & $\mathbf{M}_{1}$ & $\mathbf{M}_{2}$ & Mean \\
\hline $\mathrm{S}_{1}$ & 42.69 & 43.76 & 43.22 & 6.00 & 5.96 & 5.98 & 6.66 & 6.73 & 6.70 & 29.30 & 28.16 & 28.73 \\
\hline $\mathrm{S}_{2}$ & 44.07 & 43.04 & 43.55 & 5.33 & 5.60 & 5.46 & 6.33 & 7.20 & 6.76 & 26.83 & 26.50 & 26.66 \\
\hline $\mathrm{S}_{3}$ & 44.80 & 42.20 & 43.50 & 6.90 & 6.93 & 6.91 & 6.46 & 7.66 & 7.06 & 28.83 & 28.00 & 28.41 \\
\hline $\mathrm{S}_{4}$ & \begin{tabular}{|l|}
39.63 \\
\end{tabular} & 37.39 & 38.51 & 6.81 & 6.98 & 6.90 & 6.80 & 7.03 & 6.91 & 27.50 & 27.83 & 27.66 \\
\hline $\mathrm{S}_{5}$ & \begin{tabular}{|l|}
39.84 \\
\end{tabular} & 45.66 & 42.75 & 6.66 & 6.96 & 6.81 & 6.50 & 7.13 & 6.81 & 27.13 & 25.70 & 26.41 \\
\hline $\mathrm{S}_{6}$ & 48.72 & 46.19 & 47.46 & 6.81 & 7.56 & 7.19 & 7.13 & 7.36 & 7.25 & 28.50 & 31.65 & 30.07 \\
\hline $\mathrm{S}_{7}$ & \begin{tabular}{|l|}
41.72 \\
\end{tabular} & 49.59 & 45.66 & 6.60 & 7.61 & 7.10 & 6.46 & 6.60 & 6.53 & 31.23 & 29.70 & 30.46 \\
\hline $\mathrm{S}_{8}$ & 53.14 & 45.48 & 49.31 & 6.46 & 7.63 & 7.05 & 6.46 & 7.03 & 6.75 & 28.43 & 29.36 & 28.90 \\
\hline $\mathrm{S}_{9}$ & \begin{tabular}{|l|}
45.09 \\
\end{tabular} & 41.80 & 43.45 & 5.93 & 5.93 & 5.93 & 6.20 & 6.40 & 6.30 & 25.26 & 25.83 & 25.55 \\
\hline \multirow[t]{2}{*}{ Mean } & 44.41 & 43.90 & - & 6.39 & 6.80 & - & 6.55 & 7.01 & - & 28.11 & 28.08 & - \\
\hline & \multicolumn{2}{|c|}{ S.Em \pm} & C.D. @ 5\% & \multicolumn{2}{|l|}{ S.Em \pm} & C.D. @ 5\% & \multicolumn{2}{|c|}{ S.Em \pm} & C.D. @ 5\% & \multicolumn{2}{|c|}{ S.Em \pm} & C.D. @ 5\% \\
\hline $\mathrm{M}$ & \multicolumn{2}{|c|}{0.90} & NS & \multicolumn{2}{|l|}{0.04} & 0.29 & \multicolumn{2}{|c|}{0.09} & 0.58 & \multicolumn{2}{|l|}{0.15} & NS \\
\hline $\mathrm{S}$ & \multicolumn{2}{|l|}{1.70} & 4.89 & 0.13 & & 0.37 & 0.18 & & 0.53 & \multicolumn{2}{|l|}{0.81} & 2.34 \\
\hline $\mathrm{M} \times \mathrm{S}$ & 2.44 & & 6.92 & 0.20 & & 0.53 & 0.27 & & 0.75 & 1.09 & & 3.31 \\
\hline
\end{tabular}




\begin{tabular}{|l|c|}
\hline \multicolumn{2}{|c|}{ Sub plot treatments } \\
\hline $\mathrm{S}_{1}$ & $\mathrm{GA}_{3} @ 50 \mathrm{ppm}$ in June \\
\hline $\mathrm{S}_{2}$ & $\mathrm{KNO}_{3} @ 2 \%$ in October \\
\hline $\mathrm{S}_{3}$ & Cycocel @ $1000 \mathrm{ppm}$ in September \\
\hline $\mathrm{S}_{4}$ & Cycocel @ $1500 \mathrm{ppm}$ in September \\
\hline $\mathrm{S}_{5}$ & Cycocel @ 2000 ppm in September \\
\hline $\mathrm{S}_{6}$ & $\mathrm{GA}_{3} @ 50 \mathrm{ppm}$ in June + Cycocel @ $1000 \mathrm{ppm}$ in Sept $+\mathrm{KNO}{ }_{3} @ 2 \%$ in October \\
\hline $\mathrm{S}_{7}$ & $\mathrm{GA}_{3} @ 50 \mathrm{ppm}$ in June + Cycocel @ $1500 \mathrm{ppm}$ in Sept $+\mathrm{KNO}{ }_{3} @ 2 \%$ in October \\
\hline $\mathrm{S}_{8}$ & $\mathrm{GA}_{3} @ 50 \mathrm{ppm}$ in June + Cycocel @ $2000 \mathrm{ppm}$ in Sept $+\mathrm{KNO}{ }_{3} @ 2 \%$ in October \\
\hline $\mathrm{S}_{9}$ & Control \\
\hline & Main plot treatments \\
\hline $\mathrm{M}_{1}$ & Phule Sharbati \\
\hline $\mathrm{M}_{2}$ & Sai Sharbati \\
\hline
\end{tabular}

\section{Total soluble solids ( ${ }^{\circ}$ Brix)}

The results indicated the significant differences for total soluble solids in main plot, sub plot and interaction effect. Treatment $\mathrm{M}_{2}\left(7.01^{\circ} \mathrm{Brix}\right)$ recorded highest total soluble solids followed by $\mathrm{M}_{1}\left(6.55^{\circ} \mathrm{Brix}\right)$ in main plot. In sub plot, treatment $\mathrm{S}_{6}$ with $\mathrm{GA}_{3} @ 50$ ppm in June - Cycocel @ 1000 ppm in September - $\mathrm{KNO}_{3} @ 2 \%$ in October $\left(7.25^{\circ} \mathrm{Brix}\right)$ recorded the highest total soluble solids.

The results are in conformity with the findings of Mukunda et al. (2014) ${ }^{[24]}$ with application of $\mathrm{GA}_{3} @ 50$ ppm during June CCC@1000 ppm during September - KNO 3 @2\% during October. Similar results were also reported by Debaje et al. (2011) ${ }^{[11]}$, Jagtap et al. (2013) ${ }^{[16]}$ in acid lime, Tuan and Ruey (2013) ${ }^{[33]}$ in apple and Debbarma and Hazarika (2016) ${ }^{[12]}$ in acid lime.

\section{Ascorbic acid (mg/ $100 \mathrm{ml}$ juice)}

There was no statistical significant difference found in main plot treatments. However, the maximum ascorbic acid (30.46 $\mathrm{mg} / 100 \mathrm{ml}$ juice$)$ was found in $\mathrm{S}_{7}\left(\mathrm{GA}_{3} @ 50 \mathrm{ppm}\right.$ in June Cycocel@1500 ppm in September - $\mathrm{KNO}_{3} @ 2 \%$ in October) and was found to be on par with $\mathrm{S}_{6}(30.07 \mathrm{mg} / 100$ ml juice) i.e. GA 3 @50 ppm in June-Cycocel @ 1000 ppm in September - $\mathrm{KNO}_{3} @ 2 \%$ in October, $\mathrm{S}_{8}(28.90 \mathrm{mg} / 100 \mathrm{ml}$ juice) and $S_{1}(28.73 \mathrm{mg} / 100 \mathrm{ml}$ juice). Increase in ascorbic acid may be due to the role of various plant growth regulators and chemicals in degradation of organic acids. Further, $\mathrm{GA}_{3}$ might take part in sugar and starch hydrolysis and cycocel in diverting carbohydrates into the developing fruits. It is believed that potassium might have involved in active sugar metabolism and translocation. These findings were in agreement with Debbarma and Hazarika (2016) ${ }^{[12]}$ and Ranganna et al. (2017) ${ }^{[28]}$ in acid lime respectively.

Similar results were reported by Kumar et al. (1975) ${ }^{[21]}$ in sweet lime, Jonsan et al. (1998) ${ }^{[17]}$, Kumar et al. (2012) ${ }^{[20]}$ in strawberry, Jagtap et al. (2013) ${ }^{[16]}$ and Sandhu (2013) ${ }^{[30]}$ in lemon, Meena et al. (2017) ${ }^{[23]}$ in phalsa which increase in ascorbic acid content with $\mathrm{GA}_{3}$ and Hari Om et al. (1975) ${ }^{[15]}$ in apple cv. Red Delicious, Thukral et al. (1993) ${ }^{[32]}$ in lemon cv. Pant Lemon-1 with cycocel application. Lastly, similar results were observed by Rattanpal et al. (2008) and Debaje et al. $(2011)^{[11]}$ with potassium nitrate.

\section{Total sugars (\%)}

The different concentration of plant growth regulators and chemical had showed significant differences in sub plot and their interaction but not in main plot.

The highest total sugar (1.81\%) was recorded in $\mathrm{S}_{6}\left(\mathrm{GA}_{3} @\right.$ 50 ppm in June - Cycocel @ 1000 ppm in September - $\mathrm{KNO}_{3}$ @ 2\% in October) and was significantly superior than other treatments followed by $\mathrm{S}_{7}(1.77 \%)$ and $\mathrm{S}_{8} \quad(1.71 \%)$ respectively. The lowest total sugars was recorded in control i.e. $\mathrm{S}_{9}(0.91 \%)$. It is observable that the different plant growth regulators and chemical concentrations influenced the sugar content of the treated fruits. This may be due to the promotive role of growth regulators in consistent diversion of carbohydrates into the developing fruit and hydrolysis of starch into simple sugars.

Similar findings regarding increase the total sugar have been reported by Mazumdar and Bhatt (1976) ${ }^{[22]}$ in sweet orange, Bhujbal et al. (2013) ${ }^{[6]}$ in sapota with gibberellins, Hari Om et al. (1975) ${ }^{[15]}$ in apple cv. Red Delicious with CCC, Daberao et al. (2016) ${ }^{[10]}$ in sapota with $2 \% \mathrm{KNO}_{3}+50 \mathrm{ppm}$ $\mathrm{GA}_{3}$.

\section{Reducing sugars (\%)}

The different concentration of plant growth regulators and chemical showed significant differences for reducing sugars in sub plot treatments.

Treatment $\mathrm{S}_{6}\left(\mathrm{GA}_{3} @ 50\right.$ ppm in June-Cycocel @ 1000 ppm in September - $\mathrm{KNO}_{3} @ 2 \%$ in October) recorded the highest reducing sugars $(0.87 \%)$ and was followed by $\mathrm{S}_{7}(0.85 \%)$ and $\mathrm{S}_{8}(0.81 \%)$ respectively. The lowest reducing sugar $(0.55 \%)$ was recorded in $\mathrm{S}_{2}\left(\mathrm{KNO}_{3} @ 2 \%\right.$ in October) and was on par with $S_{9}$ i.e. control. The raised concentration of reducing sugar in the treated fruits may be attributed to the prolonged attachment of fruits in the tree caused by gibberellins might have facilitated the accumulation of more carbohydrates and degradation of complex starch into simpler sugar form by alpha-amylase regulated by the gibberellins.

The results were in close proximity with the findings of Pawar et al. $(2016)^{[25]}$ wherein $\mathrm{GA}_{3} @ 50$ ppm in June + Cycocel @ $1500 \mathrm{ppm}$ in September $+\mathrm{KNO}_{3}$ @ 2\% in October recorded the maximum reducing sugar. Similar finding were reported by Mazumdar and Bhatt (1976) ${ }^{[22]}$ in sweet orange. 
Table 3: Effect of plant growth regulators and chemical on total, reducing and non- reducing sugar acid in different cultivars of acid lime.

\begin{tabular}{|c|c|c|c|c|c|c|c|c|c|}
\hline \multirow{2}{*}{ Treatments } & \multicolumn{3}{|c|}{ Total sugars (\%) } & \multicolumn{3}{|c|}{ Reducing sugar (\%) } & \multicolumn{3}{|c|}{ Non- reducing sugar $(\%)$} \\
\hline & $\mathbf{M}_{1}$ & $\mathbf{M}_{2}$ & Mean & $\mathbf{M}_{1}$ & $\mathbf{M}_{2}$ & Mean & $\mathbf{M}_{1}$ & $\mathbf{M}_{2}$ & Mean \\
\hline $\mathrm{S}_{1}$ & 1.05 & 0.99 & 1.02 & 0.64 & 0.58 & 0.61 & 0.41 & 0.40 & 0.41 \\
\hline $\mathrm{S}_{2}$ & 1.00 & 0.99 & 0.96 & 0.56 & 0.55 & 0.55 & 0.44 & 0.37 & 0.40 \\
\hline $\mathrm{S}_{3}$ & 1.34 & 1.34 & 1.34 & 0.64 & 0.63 & 0.63 & 0.70 & 0.70 & 0.70 \\
\hline $\mathrm{S}_{4}$ & 1.34 & 1.32 & 1.33 & 0.63 & 0.61 & 0.62 & 0.67 & 0.70 & 0.68 \\
\hline $\mathrm{S}_{5}$ & 1.35 & 1.34 & 1.34 & 0.61 & 0.63 & 0.62 & 0.74 & 0.71 & 0.72 \\
\hline $\mathrm{S}_{6}$ & 1.83 & 1.80 & 1.81 & 0.86 & 0.87 & 0.87 & 0.96 & 0.92 & 0.94 \\
\hline $\mathrm{S}_{7}$ & 1.76 & 1.77 & 1.77 & 0.85 & 0.86 & 0.85 & 0.92 & 0.91 & 0.91 \\
\hline $\mathrm{S}_{8}$ & 1.65 & 1.77 & 1.71 & 0.79 & 0.84 & 0.81 & 0.86 & 0.93 & 0.89 \\
\hline $\mathrm{S}_{9}$ & 0.91 & 0.91 & 0.91 & 0.56 & 0.55 & 0.56 & 0.34 & 0.35 & 0.34 \\
\hline \multirow[t]{2}{*}{ Mean } & 1.36 & 1.35 & - & 0.68 & 0.68 & - & 0.67 & 0.67 & - \\
\hline & \multicolumn{2}{|c|}{\begin{tabular}{l|l} 
S.Em \pm & \\
\end{tabular}} & C.D. @ 5\% & \multicolumn{2}{|c|}{ S.Em \pm} & C.D. @ 5\% & \multicolumn{2}{|c|}{ S.Em \pm} & C.D. @ 5\% \\
\hline $\mathrm{M}$ & \multicolumn{2}{|c|}{0.01} & NS & \multicolumn{2}{|c|}{0.00} & $\mathrm{NS}$ & \multicolumn{2}{|c|}{0.00} & NS \\
\hline $\mathrm{S}$ & \multicolumn{2}{|c|}{0.02} & 0.07 & \multicolumn{2}{|c|}{0.01} & 0.05 & \multicolumn{2}{|c|}{0.01} & 0.05 \\
\hline $\mathrm{M} \times \mathrm{S}$ & \multicolumn{2}{|c|}{0.03} & 0.10 & \multicolumn{2}{|c|}{0.02} & 0.07 & \multicolumn{2}{|c|}{0.02} & 0.07 \\
\hline
\end{tabular}

\begin{tabular}{|c|c|}
\hline \multicolumn{2}{|r|}{ Sub plot treatments } \\
\hline $\mathrm{S}_{1}$ & $\mathrm{GA}_{3} @ 50 \mathrm{ppm}$ in June \\
\hline $\mathrm{S}_{2}$ & $\mathrm{KNO}_{3} @ 2 \%$ in October \\
\hline $\mathrm{S}_{3}$ & Cycocel@1000 ppm in September \\
\hline $\mathrm{S}_{4}$ & Cycocel @ 1500 ppm in September \\
\hline $\mathrm{S}_{5}$ & Cycocel @ 2000 ppm in September \\
\hline $\mathrm{S}_{6}$ & $\mathrm{GA}_{3} @ 50 \mathrm{ppm}$ in June + Cycocel @ $1000 \mathrm{ppm}$ in Sept + $\mathrm{KNO}_{3} @ 2 \%$ in October \\
\hline $\mathrm{S}_{7}$ & $\mathrm{GA}_{3} @ 50 \mathrm{ppm}$ in June + Cycocel @ $1500 \mathrm{ppm}$ in Sept + $\mathrm{KNO}_{3} @ 2 \%$ in October \\
\hline $\mathrm{S}_{8}$ & $\mathrm{GA}_{3} @ 50 \mathrm{ppm}$ in June + Cycocel @ $2000 \mathrm{ppm}$ in Sept + $\mathrm{KNO}_{3} @ 2 \%$ in October \\
\hline $\mathrm{S}_{9}$ & Control \\
\hline \multicolumn{2}{|r|}{ Main plot treatments } \\
\hline $\mathrm{M}_{1}$ & Phule Sharbati \\
\hline $\mathrm{M}_{2}$ & Sai Sharbati \\
\hline
\end{tabular}

\section{Non-reducing sugars $(\%)$}

The data showed in Table 3 had significantly influenced non reducing sugar content of acid lime with different concentrations of plant growth regulators and chemical in sub plot only.

The highest non reducing sugars $(0.94 \%)$ was recorded in $\mathrm{S}_{6}$ $\left(\mathrm{GA}_{3} @ 50\right.$ ppm in June - Cycocel @ 1000 ppm in September - $\mathrm{KNO}_{3} @ 2 \%$ in October) which was followed by $\mathrm{S}_{7}(0.91 \%)$ and $\mathrm{S}_{8}(0.89 \%)$ respectively. The lowest non reducing sugar was recorded in $\mathrm{S}_{9}(0.34 \%)$ i.e. control. The results were in close proximity with the findings of Pawar et al. (2016) [25] wherein $\left(\mathrm{GA}_{3} @ 50\right.$ ppm in June + Cycocel @ 1500 ppm in September $+\mathrm{KNO}_{3} @ 2 \%$ in October) recorded the maximum non-reducing sugar.

Similar finding were reported by Mazumdar and Bhatt (1976) ${ }^{[22]}$ in sweet orange, Hari Om et al. (1975) ${ }^{[15]}$ in apple cv. Red Delicious and Bhatt et al. (2017) ${ }^{[4]}$ in Pant lemon-1.

\section{Number of seeds per fruit (g)}

There was no statistical significant differences found in main plot and interactions however significant differences was found in sub plot for number of seeds per fruit (g) (Table 4).

However, in sub plot, the minimum number of seeds $(8.06 \mathrm{~g})$ was recorded in $\mathrm{S}_{6}\left(\mathrm{GA}_{3} @ 50\right.$ ppm in June - Cycocel @ 1000 ppm in September - $\mathrm{KNO}_{3} @ 2 \%$ in October) but was on par with $S_{7}(9.00 \mathrm{~g}), \mathrm{S}_{1}(9.20 \mathrm{~g}), \mathrm{S}_{8}(9.60 \mathrm{~g}), \mathrm{S}_{2}(10.03 \mathrm{~g})$ and $\mathrm{S}_{3}$ $(10.30 \mathrm{~g})$ respectively. The reduction in seed number of the fruits was seen only in the treatment containing gibberellins. This indicated that gibberellins were involved in the physiology of seed development thereby reducing the seed number. However, gibberellins may also be involved in stimulation of parthenocarpic fruit development phenomena. Similar results were reported by Debaje et al. $(2011)^{[11]}$ with $\mathrm{GA}_{3} 100$ ppm, Garasiya et al. (2013) ${ }^{[14]}$ with $\mathrm{GA}_{3} 50 \mathrm{ppm}$ in guava, Jagtap et al. (2013) ${ }^{[16]}$ Bhatt et al. (2016) ${ }^{[5]}$ in lemon.
Randhawa et al. (1964) [27] also reported decreased seed number in guava and grapefruit with GA 3 @ 100 ppm.

\section{Weight of seeds per fruit (g)}

There were statistical significant differences found in main plot, sub plot and their interactions as data showed in Table 4. The least weight of seeds per fruit $(0.62 \mathrm{~g})$ was observed in $S_{1}$ $\left(\mathrm{GA}_{3} @ 50 \mathrm{ppm}\right.$ in June) and was found to be on par with $\mathrm{S}_{6}$ $(0.63 \mathrm{~g})$ i.e. $\left(\mathrm{GA}_{3} @ 50\right.$ ppm in June - Cycocel @ 1000 ppm in September - $\mathrm{KNO}_{3} @ 2 \%$ in October) followed by $\mathrm{S}_{7}(0.65$ g) i.e. $\left(\mathrm{GA}_{3} @ 50 \mathrm{ppm}\right.$ in June - Cycocel @ $1500 \mathrm{ppm}$ in September - $\mathrm{KNO}_{3} @ 2 \%$ in October). However, the highest weight of seeds was observed in $\mathrm{S}_{9}(0.88 \mathrm{~g})$ i.e. control. It is clear that the treatment which contained gibberellins showed relatively lower seed weight as compared to the ones which do not contained gibberellins. It indicated that gibberellins may have played some physiological intervention in fruit development with rudimentary seeds.

These results were in similarity with the findings of Chaudhari et al. (1992) who reported reduced seed weight with $\mathrm{GA}_{3} @ 40$ ppm.

\section{Rind thickness (mm)}

The data presented in Table 4 showed that the application of different concentration of growth regulators and chemical had significantly influenced the rind thickness of the acid lime.

As regard to main plot, the least rind thickness $(1.47 \mathrm{~mm})$ was observed in $\mathrm{M}_{2}$ (Sai Sharbati) and followed by $\mathrm{M}_{1}(1.67 \mathrm{~mm})$ i.e. Phule Sharbati. In sub plot, $\mathrm{S}_{8}\left(\mathrm{GA}_{3} @ 50 \mathrm{ppm}\right.$ in June Cycocel@2000 ppm in September - $\mathrm{KNO}_{3} @ 2 \%$ in October) recorded the least rind thickness $(1.45 \mathrm{~mm})$ and found to be significantly different than other treatments but on par with $\mathrm{S}_{6}(1.46 \mathrm{~mm})$ i.e. $\mathrm{GA}_{3} @ 50$ ppm in June Cycocel @ 1000 ppm in September - $\mathrm{KNO}_{3} @ 2 \%$ in October followed 
by $S_{2}(1.46 \mathrm{~mm}), S_{9}(1.51 \mathrm{~mm}), S_{5}(1.55 \mathrm{~mm}), S_{7}(1.56 \mathrm{~mm})$ and $\mathrm{S}_{1}(1.60 \mathrm{~mm})$ respectively.

The obtained results were in close conformity with the findings of Debaje et al. (2011) ${ }^{[11]}$ where peel percentage were reduced with $\mathrm{KNO}_{3} @ 2$ per cent and $\mathrm{GA}_{3} 100$ ppm and Sharma and Randhawa (1966) ${ }^{[31]}$ reported decrease in rind thickness with $\mathrm{GA}_{3} @ 50$ ppm. However, the results found to be contradictory with the findings of Daberao et al. (2016) ${ }^{[10]}$ who reported maximum peel weight with two percent $\mathrm{KNO}_{3}+$ 50 ppm GA 3 , Chundawat and Randhawa (1972) [9] in grapefruit var. Saharanpur Special and Dinar et al. (1977) ${ }^{[13]}$ in Marsh grapefruit with $\mathrm{GA}_{3}$.

Table 4: Effect of plant growth regulators and chemical on number of seeds, weight of seeds per fruit and rind thickness in different cultivars of acid lime

\begin{tabular}{|c|c|c|c|c|c|c|c|c|c|}
\hline \multirow{2}{*}{ Treatments } & \multicolumn{3}{|c|}{ Number of seeds per fruit } & \multicolumn{3}{|c|}{ Weight of seeds per fruit (g) } & \multicolumn{3}{|c|}{ Rind thickness (mm) } \\
\hline & $\mathbf{M}_{1}$ & $\mathbf{M}_{2}$ & Mean & $M_{1}$ & $\mathbf{M}_{2}$ & Mean & $M_{1}$ & $\mathbf{M}_{2}$ & Mean \\
\hline $\mathrm{S}_{1}$ & 7.87 & 10.53 & 9.20 & 0.62 & 0.63 & 0.62 & 1.65 & 1.50 & 1.60 \\
\hline $\mathrm{S}_{2}$ & 11.00 & 9.06 & 10.03 & 0.72 & 0.78 & 0.75 & 1.48 & 1.39 & 1.46 \\
\hline $\mathrm{S}_{3}$ & 10.13 & 10.46 & 10.30 & 0.69 & 0.78 & 0.73 & 2.22 & 1.57 & 1.87 \\
\hline $\mathrm{S}_{4}$ & 11.60 & 9.80 & 10.70 & 0.71 & 0.77 & 0.74 & 1.94 & 1.51 & 1.70 \\
\hline $\mathrm{S}_{5}$ & 11.73 & 10.00 & 10.86 & 0.70 & 0.78 & 0.74 & 1.69 & 1.43 & 1.55 \\
\hline $\mathrm{S}_{6}$ & 8.80 & 7.33 & 8.06 & 0.62 & 0.64 & 0.63 & 1.44 & 1.43 & 1.46 \\
\hline $\mathrm{S}_{7}$ & 10.33 & 8.86 & 9.00 & 0.62 & 0.67 & 0.65 & 1.65 & 1.49 & 1.56 \\
\hline $\mathrm{S}_{8}$ & 10.33 & 8.87 & 9.60 & 0.78 & 0.70 & 0.74 & 1.49 & 1.42 & 1.45 \\
\hline $\mathrm{S}_{9}$ & 11.46 & 11.13 & 11.30 & 0.87 & 0.89 & 0.88 & 1.53 & 0.97 & 1.51 \\
\hline \multirow[t]{2}{*}{ Mean } & 10.22 & 9.57 & - & 0.70 & 0.74 & - & 1.67 & 1.47 & - \\
\hline & \multicolumn{2}{|l|}{ S.Em \pm} & C.D. @ 5\% & \multicolumn{2}{|c|}{ S.Em \pm} & C.D. @ 5\% & \multicolumn{2}{|c|}{ S.Em \pm} & C.D. @ 5\% \\
\hline $\mathrm{M}$ & \multicolumn{2}{|l|}{0.68} & NS & \multicolumn{2}{|c|}{0.03} & NS & \multicolumn{2}{|c|}{0.02} & 0.14 \\
\hline $\mathrm{S}$ & \multicolumn{2}{|l|}{0.83} & 3.19 & \multicolumn{2}{|c|}{0.02} & 0.06 & \multicolumn{2}{|c|}{0.06} & 0.20 \\
\hline $\mathrm{M} \times \mathrm{S}$ & \multicolumn{2}{|l|}{1.29} & NS & \multicolumn{2}{|c|}{0.03} & 0.08 & \multicolumn{2}{|c|}{0.09} & 0.30 \\
\hline
\end{tabular}

\begin{tabular}{|c|c|}
\hline \multicolumn{2}{|c|}{ Sub plot treatments } \\
\hline $\mathrm{S}_{1}$ & $\mathrm{GA}_{3} @ 50 \mathrm{ppm}$ in June \\
\hline $\mathrm{S}_{2}$ & $\mathrm{KNO}_{3} @ 2 \%$ in October \\
\hline $\mathrm{S}_{3}$ & Cycocel @ $1000 \mathrm{ppm}$ in September \\
\hline $\mathrm{S}_{4}$ & Cycocel @ $1500 \mathrm{ppm}$ in September \\
\hline $\mathrm{S}_{5}$ & Cycocel @ 2000 ppm in September \\
\hline $\mathrm{S}_{6}$ & $\mathrm{GA}_{3} @ 50 \mathrm{ppm}$ in June + Cycocel @ $1000 \mathrm{ppm}$ in Sept $+\mathrm{KNO}_{3} @ 2 \%$ in October \\
\hline $\mathrm{S}_{7}$ & $\mathrm{GA}_{3} @ 50 \mathrm{ppm}$ in June + Cycocel @ $1500 \mathrm{ppm}$ in Sept $+\mathrm{KNO}_{3} @ 2 \%$ in October \\
\hline $\mathrm{S}_{8}$ & $\mathrm{GA}_{3} @ 50 \mathrm{ppm}$ in June + Cycocel @ 2000 ppm in Sept $+\mathrm{KNO}_{3} @ 2 \%$ in October \\
\hline $\mathrm{S}_{9}$ & Control \\
\hline & \\
\hline $\mathrm{M}_{1}$ & Main plot treatments: \\
\hline $\mathrm{M}_{2}$ & Phule Sharbati \\
\hline
\end{tabular}

\section{Yield per tree $(\mathrm{kg} / \mathrm{tree})$}

The data regarding yield per tree (kg/tree) showed nonsignificant difference in main plot as depicted in Figure 1. However, there were statistical significant differences found among the sub plot treatments. The maximum yield per tree was observed in $\mathrm{S}_{6}(14.93)$ and significantly superior over all other treatments and on par with $S_{7}$ (12.82). However, the minimum yield per tree was observed in $\mathrm{S}_{9}$ (7.11).

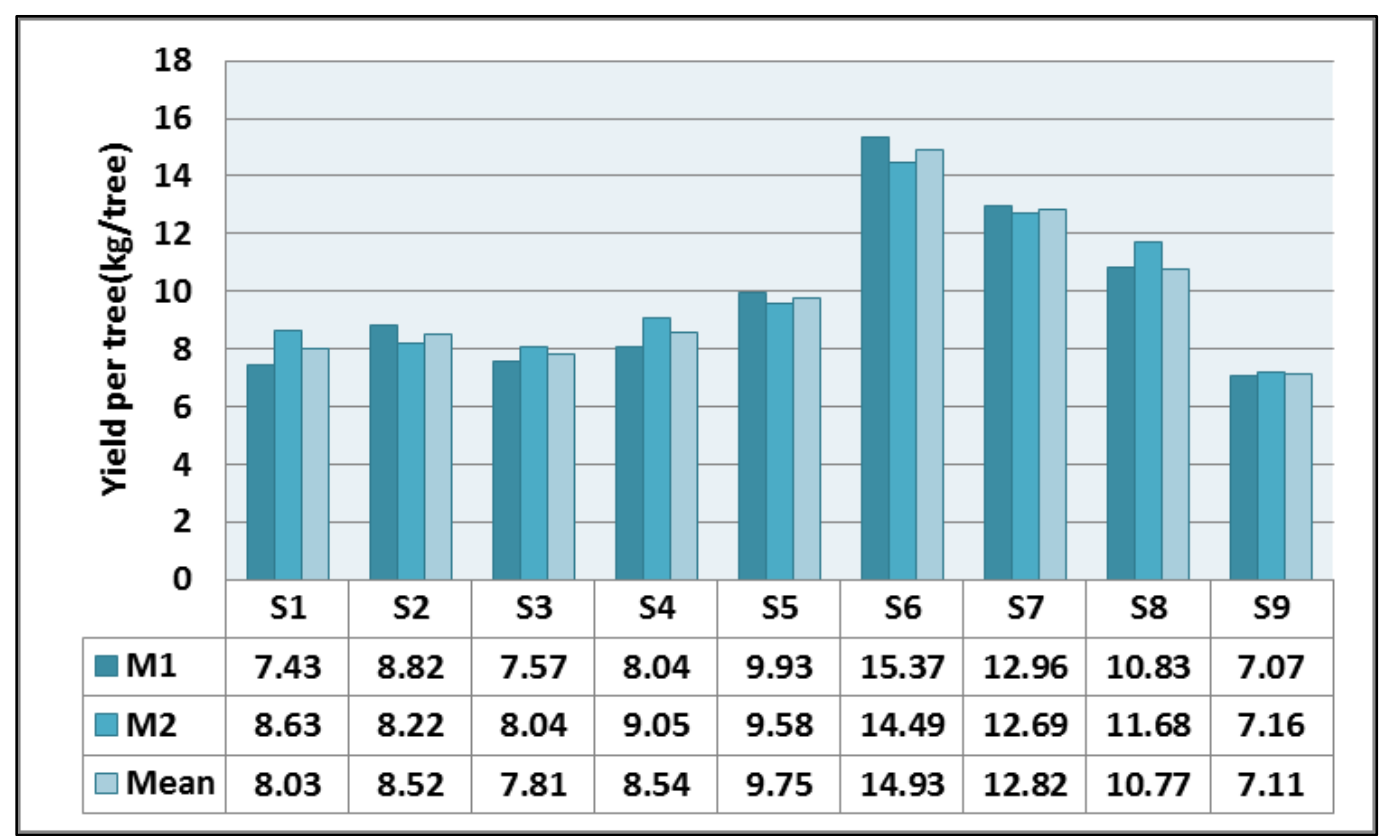

Fig 1: Shows yield tree $(\mathrm{kg} / \mathrm{tree})$ 


\section{Acknowledgement}

The authors are thankful to Professor and Head, Department of Fruit Science, College of Horticulture, Bagalkot, Dean, College of Horticulture, Bagalkot as well as the Director of Research and Dean Post Graduate Studies, University of Horticultural Sciences, Bagalkot for providing all the necessary facilities during the course of the study. We, sincerely extend our profound thanks and gratitude to ICAR, New Delhi, for providing non-JRF fellowship during the study.

\section{References}

1. Anonymous. Horticulture Statistics at a Glance, 2017, 141-142.

2. AOAC. Official and tentative methods of analysis. Association of Agricultural Chemists. 12 $2^{\text {th }}$ Ed. Washington, D.C, 1975.

3. Baghdady GA, Abdelrazik AM, Abdrabboh GA, AboElghit AA. Effect of foliar application of $\mathrm{GA}_{3}$ and some nutrients on yield and fruit quality of Valencia orange trees, Nature and Science. 2014; 12(4).

4. Bhatt BB, Singh KK, Rawat SS, Influence of foliar application of bio-regulators and nutrients on the fruit quality of Lemon (Citrus limon Burma.) cv. Pant Lemon1. Int. J Curr. Microbiol. App. Sci. 2017; 6(4):2451-2458.

5. Bhatt BB, Rawat SS, Naithani DC, Kumar D, Singh KK. Effect of foliar application of bio-regulators and nutrients on growth and yield characters of lemon (Citrus limon Burma.) cv. Pant lemon-1 under subtropical condition of Garhwal region. Plant Archives. 2016; 16(2):821-825.

6. Bhujbal DS, Naik DM, Kale SA. Studies on effect of growth regulators on flowering, fruiting and quality of sapota. Int. J Agri. Sci. 2013; 9(1):289-292.

7. Brahmchari VS, Mandal AK, Kumar R, Rani R. Effect of growth substance on fruit-set and physico-chemical characteristics of 'Sardar' guava (Psidium guajava L.) Recent Hort. 1995; 2:127-131.

8. Chaudhari AS, Singh M, Singh GN. Effect of plant growth regulators on loquat cv. Herds mammoth. Punjab Hort. J. 1992; 32:99-102.

9. Chundawat BS, Randhawa GS. Effect of plant growth regulators on fruit set, fruit drop and quality of Saharanpur variety of grapefruit. Indian J Horti. 1972; 29:277-282.

10. Daberao MD, Joshi PS, Satkar K. Effect of growth promoting substances on the fruit quality of rejuvenated sapota orchard. The Bioscan. 2016; 11(1):301-303.

11. Debaje P, Shinde P, Ekta D, Ingale HV. Effect of plant growth regulators and nutrients on quality of Acid lime (Citrus aurantifolia Swingle). Asian J Horti. 2011; 6(1):253-255.

12. Debbarma N, Hazarika BN. Effect of plant growth regulators and chemicals on yield and quality of acid lime (Citrus aurantifolia Swingle) under foothill condition of Arunachal Pradesh. Int. J Agri. Env. Biotechn, 2016, 434.

13. Dinar HMA, Krezdorn AH, Rose AJ. Extending the grapefruit harvest season with growth regulators. Proceedings of Florida State Horticulture Society. 1977; 89:4-6.

14. Garasiya VR, Patel NM, Bhadauria HS, Wankhade VR. Studies of plant growth substances on the yield components of winter season guava cv. L-49 (Sardar). International J Agri. Sci. 2013; 9(1):114-116.
15. Hari Om, Shrivastava RP, Misra RS, Bana DS. Effect of growth substances on drop, fruit retention and quality of apple cv. Red Delicious. Prog. Horti. 1975; 7(1):57-66.

16. Jagtap VM, Patel HC, Nehete DS, Godage SS. Effect of foliar application of plant growth regulators and micronutrients on yield and quality of acid lime cv. Kagzi (Citrus aurantifolia Swingle). Asian J Hort. 2013; 8:5759.

17. Jonsan JS, Sandhu AS, Singh R. Qualitative changes in the fruits of Baramasi lemon as influenced by plant growth regulators. Res. J Punjab Agri. Uni. 1998; 35:4152.

18. Khalid S, Malik AU, Khan AS, Jamil A. Influence of exogenous applications of plant growth regulators on fruit quality of young 'Kinnow' Mandarin (Citrus nobilis $\times$ C. deliciosa) trees. Int. J Agric. Biol. 2012; 14(2):229234.

19. Khayyat M, Tehranifar A, Zaree M, Karimian Z, Aminifard MH, Vazifeshenas MR et al. Effects of potassium nitrate spraying on fruit characteristics of 'MalasYazdi' pomegranate. J Plant Nutrition. 2012; 35:1387-1393.

20. Kumar R, Bakshi M, Singh DB. Influence of plant growth regulators on growth, yield and quality of strawberry under U.P. sub tropics. Asian Journal of Horticulture. 2012; 7(2):434-436.

21. Kumar R, Singh JP, Gupta OP. Effect of growth regulators on fruit set, fruit drop and quality of Sweet lime (Citrus lamettioides Tanaka.). Haryana J. Hort. Sci. 1975; 4:123-129.

22. Mazumdar BC, Bhatt DNV. Effect of pre-harvest application of GA and ethrel on sweet orange (Citrus sinensis Osbeck) fruits. Prog. Hort. 1976; 8:89-91.

23. Meena AK, Singh AK, Singh B. A review on effect of plant growth regulators on physico-chemical attributes of phalsa (Grewia subinaequalis D.C.). Int. J. Curr. Microbiol. Applied Sci. 2017; 6(5):1929-1938.

24. Mukunda LL, Ramana KTV, Sivarama K, Yuvaraj KM, Lakshmi TN, Sarada G et al. Effect of growth regulators and chemicals fruit yield and quality of hasta bahar flowering in acid lime (Citrus aurantifolia Swingle.) cv. Balaji. J Agri. and Allied Sci. 2014; 3:11-13.

25. Pawar PS, Jagtap DD, Patil DD. Effect of plant growth regulators and chemicalsonyield of Acidlime (Citrus aurantifolia Swingle) during hasta bahar. Bioinfolet. 2016; 13:176-178.

26. Pawar PS, Jagtap DD, Garad BV, Shirsath HK. Effect of plant growth regulators on maturity, yield and fruit weight of Pomegranate cv. Mridula. J Adv. Pl. Sci. 2005; 18(1):167-170.

27. Randhawa GS, Dhuria HS, Nair PK. A note on gibbereliin induced parthenocarpy in citrus. Indian $\mathrm{J}$. Hort. 1964; 21:171-172.

28. Ranganna GKT, Venkataramana L, Mukundalakshmi K, Swarajyalakshmi, Sudhakar P. Effect of plant growth regulators on yield and quality parameters of summer crop in acid lime (Citrus aurantifolia Swingle) cv. Balaji. Int. J Curr. Microbiol. Applied Sci. 2017; 6(6):21932199.

29. Rokaya PR, Baral DR, Gautam DM, Shrestha AK, Paudyal KP. Effect of pre- harvest application of gibberellic acid on fruit quality and shelf life of mandarin (Citrus reticulata Blanco) American J Pl. Sci. 2016; 07:1-7. 
30. Sandhu S. Improving lemon (Citrus limon) quality using growth regulators. J Horti. Sci. 2013; 8(1):88-90.

31. Sharma RB, Randhawa G. Studies on fruit set and fruit drop in citrus. The Indian J Horti. 1966; 23:12-20.

32. Thukral BR, Singh R, Misra KK, Jaiswal HR. Effect of growth regulators on regulation of crop and fruit quality in lemon (Citrus limon Burn.). Ann. Agri. Res. 1993; 14 (3):322-326.

33. Tuan N, Ruey YC. Effect of gibberellic acid and 2, 4dichlorophenoxyacetic acid on fruit development and fruit quality of wax apple. World Acad. Sci. Engineering \& Techn, 2013, 77. 